Научная статья

УДК 343.72(470+517.3)

DOI 10.18101/2658-4409-2021-3-40-45

\title{
МОШЕННИЧЕСТВО В КИБЕРПРОСТРАНСТВЕ ПО УГОЛОВНОМУ ЗАКОНОДАТЕЛЬСТВУ РОССИИ И МОНГОЛИИ
}

\author{
(C) Семенова Наталья Александровна \\ преподаватель \\ 624559@list.ru
}

\section{(C) Эрхитуева Татьяна Ильинична}

кандидат юридических наук, доцент

tanja_77@mail.ru

\section{Бурятский государственный университет имени Доржи Банзарова} Россия, 670000, г. Улан-Удэ, ул. Сухэ-Батора, 6

\begin{abstract}
Аннотация. Российско-монгольские отношения опираются на многолетнюю историю двустороннего взаимодействия, отличаются традиционным добрососедством, носят всеобъемлющий характер. Борьба с киберхищениями занимает особое место в России, а также в Монголии.

В уголовном законодательстве обеих стран предусматривается уголовная ответственность за мошенничество в сфере информационно-телекоммуникационных технологий или компьютерной информации.

Исследование данного вида мошенничества также актуально, поскольку в 2016 г. был принят новый Уголовный кодекс Монголии. В связи с этим представляет интерес уголовно-правовое регулирование мошенничества, совершаемого в киберпространстве, в Монголии. В уголовном законодательстве России и Монголии существуют некоторые различия в определении мошенничества, вместе с тем паттерны социальной инженерии, используемые мошенниками в обеих странах, практически ничем не различаются.
\end{abstract}

Ключевые слова: уголовное право, преступления, профилактика преступлений, киберпреступность, киберпространство, мошенничество, хищение.

\section{Для цитирования}

Семенова Н. А., Эрхитуева Т. И. Мошенничество в киберпространстве по уголовному законодательству России и Монголии // Вестник Бурятского государственного университета. Юриспруденция. 2021. Вып. 3. С. 40-45.

В настоящее время уделяется много внимания вопросам сотрудничества со странами АТР. Особое место здесь занимает сотрудничество России с Монголией. Для нормального диалога обеих стран важное значение имеет сотрудничество государств по разным вопросам, в том числе по вопросам профилактики и предупреждения разного рода преступлений.

Особенно актуальным является сотрудничество в области профилактики и предупреждения киберпреступлений. Интересным является то, как отдельные 
Н. А. Семенова, Т. И. Эрхитуева. Мошенничество в киберпространстве по уголовному законодательству России и Монголии

страны ведут борьбу с мошенничеством в сфере информационно-телекоммуникационных технологий или компьютерной информации.

В 2017 г. в Монголии стал действовать новый Уголовный кодекс, принятый в 2016 г. В связи с этим представляется интересным исследовать уголовно-правовое преследование мошенничества, совершаемого в Монголии в киберпространстве.

В киберпространстве наиболее распространенными преступлениями являются хищения, совершаемые обманным путем. К ним следует отнести: платежное мошенничество, то есть хищение с использованием платежных карт; скиммингпреступления, связанные с использованием для мошенничества банкоматов; вредоносный платежный софт - хищение посредством разработки и использования вредоносных программ; социальный инжиниринг - незаконное получение в корыстных целях информации; фишинг - получение доступа к конфиденциальным данным личности путем рассылки электронных писем; мошенничество в электронной торговле; мошенничество с предоплатой [1, с. 215-221].

Так, по данным Генеральной прокуратуры Российской Федерации, наиболее распространены мошенничества в сфере информационно-телекоммуникационных технологий или компьютерной информации. На них приходится около $70 \%$ всех хищений, совершенных путем обмана или злоупотребления доверием. При совершении 25,8 тыс. мошенничеств использовались электронные средства платежа. Всего за последние пять лет число таких преступлений увеличилось более чем в 11 раз, а удельный вес в структуре преступности возрос с 1,8 до $25 \%[2, \text { с. } 6]^{1}$.

В Монголии распространены такие преступления в сфере информационных технологий, как мошенничество, вымогательство через электронную почту и скимминг. Мошенничество в киберпространстве происходит через интернет-покупки, рассылку СМС на электронную почту о возможности выиграть деньги в крупном размере, письма о наследстве, о помощи, просьбы прислать счет кредита и т. д.

Начиная с 2012 г. на территории Монголии выявлен ряд хищений крупных сумм денег с использованием фальшивых кредитных карт из банкоматов коммерческих банков гражданами Украины и Малайзии [3, с. 3].

Согласно уголовному законодательству Российской Федерации ответственность за мошенничество предусматривается ст. 159.3 УК РФ. Мошенничество с использованием электронных средств платежа — ст. 159.6 УК РФ.

В Уголовном кодексе Монголии 2016 г. ответственность за мошенничество в киберпространстве предусмотрена ст. 17.3 УК Монголии. Согласно норме мошенничеством является обращение виновным в свою пользу имущества или права на имущество владельца или собственника путем обмана или использования документов, предметов и электронных средств, либо создания искусственных ситуаций, использования суеверия и введения другого лица в заблуждение путем сокрытия реального положения дел, а также злоупотребления авторитетом и доверием, возникшими в результате прежних отношений [3, с. 69].

Мошенничество, согласно исследуемой норме, содержит в себе два признака. Во-первых, это обращение в свою пользу имущества или права на имущество

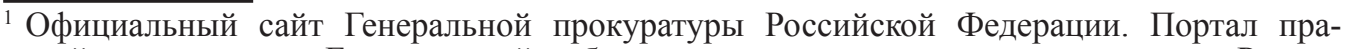
вовой статистики. Ежемесячный сборник о состоянии преступности в России за декабрь 2020 г. URL: // http://crimestat.ru/analytics (дата обращения : 28.06.2021). Текст : электронный.
} 
владельца или собственника. Во-вторых, такое обращение происходит путем обмана. В отличие от УК Монголии УК РФ определяет мошенничество как хищение чужого имущества или приобретение права на чужое имущество путем обмана или злоупотребления доверием.

Таким образом, по законодательству обеих стран главным способом мошенничества выступают обман и другие альтернативные варианты или способы, которые строятся на основе обмана.

В Уголовном кодексе Монголии в статье «Мошенничество» содержатся такие варианты обмана, как моделирование разнообразных ситуаций, использование авторитета, суеверие, сокрытие реального положения дел. Отдельно в части 3.2 статьи 17.3 УК Монголии выделяется такой способ осуществления обмана, как «многоступенчатый маркетинг или система пирамиды» $[4, \text { с. } 70]^{1}$. В Уголовном кодексе Российской Федерации подобная деятельность, как правило, подпадает под отдельную статью «Организация деятельности по привлечению денежных средств и (или) иного имущества» (ст. 172.2).

Интернет-мошенничество отличается тем, что обман приобретает особую форму. Это не просто намеренные действия по искажению или сокрытию информации, а целая система таких действий, представляющая собой паттерны социальной инженерии, то есть мошеннические схемы, в основе которых лежат приемы манипуляций сознанием потенциальных жертв, при помощи которых злоумышленники понуждают людей осуществлять выгодные для преступников действия.

Несмотря на некоторые различия в определении мошенничества в уголовном законодательстве России и Монголии, паттерны социальной инженерии, используемые мошенниками в обеих странах, практически ничем не различаются. Более того, учитывая то, что граждане Монголии часто хорошо понимают русский язык и используют российские социальные сети, а жители Республики Бурятия, находящиеся в составе РФ, иногда неплохо владеют монгольским языком, социальная инженерия является весьма актуальным способом совершения мошенничества.

Если говорить о понятии электронных средств, то под это определение в России и Монголии подпадают электронные средства платежа и электронные средства связи.

В соответствии с федеральным законом от 27.06.2011 № 161-Ф3 (ред. от 22.12.2020) «О национальной платежной системе» (с изм. и доп., вступ. в силу с 01.01.2021) электронное средство платежа — средство и (или) способ, позволяющие клиенту оператора по переводу денежных средств составлять, удостоверять и передавать распоряжения в целях осуществления перевода денежных средств в рамках применяемых форм безналичных расчетов с использованием информационно-коммуникационных технологий, электронных носителей информации, в том числе платежных карт, а также иных технических устройств. К электронным средствам платежа относятся банковские карточки (как дебетовые, так кредитные), а также «Клиент-банк», устанавливаемый на компьютер клиента, чтобы он мог формировать платежные поручения и в электронном виде пересылать их в обслуживающий банк для проведения платежей.

\footnotetext{
${ }^{1}$ Уголовный кодекс Монголии / пер. с монг. Амарсанаа, Вандан-Иш, Батболд Галбадрах; науч. ред. перевода и предисл. М. В. Бавсуна, А. А. Нечепуренко. Омск : Изд-во Омской академии МВД России, 2020. 144 с. Текст : непосредственный.
} 
Н. А. Семенова, Т. И. Эрхитуева. Мошенничество в киберпространстве по уголовному законодательству России и Монголии

Платежная система представляет собой сервис для перевода денег или иных средств, их заменяющих (чеки, сертификаты, условные платежные единицы или специализированные ценные бумаги), в электронной или физической форме, при помощи которой можно осуществлять платежи без карты, с виртуальной карты или при помощи полноценной пластиковой карты, заказываемой через платежный сервис. В России это система Яндекс.Деньги, система WebMoney и т. д., в Монголии - это Migom и другие системы.

Электронные средства связи можно определять как технические и программные средства, используемые для формирования, приема, обработки, хранения, передачи, доставки сообщений в форме электронных сообщений (документов), в виде электрических (электронных) сигналов, посылаемых по проводам, кабелю, оптоволоконным линиям или вообще без направляющих линий. Подобное определение целесообразно было бы закрепить в законодательстве Монголии и России. Полагаем, что это облегчило бы толкование соответствующих статей уголовного кодекса и устранило бы часто возникающую путаницу в определениях.

К электронным средствам связи, используемым интернет-мошенниками, можно отнести смартфоны, компьютеры и другие электронные устройства, используемые для целей передачи информации посредством сети Интернет, например, «IPad».

Интересным представляется тот факт, что многие граждане Монголии являются активными пользователями российской социальной сети «Вконтакте» и некоторые из них становятся жертвами мошеннических действий со стороны граждан России. Российские граждане охотно прибегают к мошенническим действиям в отношении граждан Монголии, так как велика вероятность того, что они не будут пойманы в случае заявления в полицию. Но чаще их надежды на безнаказанность связаны с тем, что о преступлении вообще не будет заявлено, ведь в сегменте мошенничества в социальных сетях процент латентных преступлений невероятно высок. Причинами того является не только языковой барьер, но и разные традиции и ментальность народов. Для гражданина Монголии публично признаться в том, что он стал жертвой интернет-мошенников из России весьма нелицеприятно, и эту особенность этнопсихологии также используют мошенники. Только тогда, когда мошенничество приобретает массовый характер, люди все же заявляют в полицию. Нередко международное сотрудничество в области информационной безопасности дает свои плоды в виде раскрытых преступлений или совместных профилактических мероприятий.

Одним из наиболее распространенных способов интернет-мошенничества с использованием социальной инженерии, процветающих в Монголии и России, является «романтическое знакомство в интернете». Актуальность данного вида мошенничества в этих странах остается весьма высокой. Такое положение вещей связано с тем, что уровень жизни в России и Монголии примерно одинаково невысокий, это в совокупности с низким уровнем информированности о жизни в соседнем государстве порождает у жертв ложные представления о больших перспективах и высоких доходах граждан другой страны.

Основные паттерны социальной инженерии, используемые мошенниками в данном случае, строятся на психологических подходах к изучению личности. Мошенники выбирают не случайных жертв, а изучают сначала страницы 
в соцсети, составляют профиль личности, а затем же начинают свои атаки. Вопреки расхожему мнению жертвами «брачных мошенников» становятся не только женщины, но и мужчины.

Схема довольно проста, но очень эффективна. Во-первых, что российские, что монгольские женщины свободны от социальных стереотипов и без смущения показывают свой семейный статус в сети Интернет («без пары», «в активном поиске» и тому подобное). При этом если на странице демонстрируется наличие личного автотранспорта, отдых на курортах, украшения, разнообразная одежда, то все это дает мошеннику информацию о том, что владелица страницы хорошо пойдет на контакт. Во-вторых, и россиянки, особенно из Бурятии, и монголки не просто не имеют каких-то национальных предрассудков, но более того, очень активно идут на контакт с представителями соседней страны. Ввиду многогранной, исторической связи российского и монгольского народов установка на личные взаимосвязи в виде архетипа встроена в подсознание наших граждан и используется социальными инженерами не только в целях развития и укрепления, сотрудничества и международных связей, но и в мошеннических схемах.

По информации монгольских СМИ, в целях профилактики такого вида мошенничества Министерство внешних сношений и экономического сотрудничества предупреждает женщин быть бдительными при знакомствах в социальных сетях.

В России также проводятся профилактические мероприятия, включая сотрудничество с социальными сетями и ведение информационной политики, направленной на противодействие мошенничеству в Интернете.

В качестве профилактики интернет-мошенничества в обеих странах, как уже отмечалось, применяются разнообразные методы, но необходимо учесть, что для достижения успеха важно предлагать гражданам обеих стран более широкие возможности доступа к информационным ресурсам. Такими ресурсами являются, совместные российско-монгольские сообщества, например «Онлайн-Монголия - Монголы - Монголчууд», находящееся в российской социальной сети «Вконтакте», сообщество «Монголия» в социальной сети «Facebook» и многие другие международные электронные порталы типа «Central Asia. media», paзнообразные медиаблоги и другие электронные ресурсы.

Размещение профилактической информации о видах международного интернет-мошенничества на данных порталах, подробные разъяснения, куда и каким образом обратиться в случае мошеннических действий или при подозрении на такие действия, вне всякого сомнения, приведет к уменьшению преступлений такого характера. Если же создать общественное подразделение международной волонтерской службы по борьбе с мошенничеством в социальных сетях, то очевидно, что это не только приведёт к снижению случаев мошенничества, но и будет содействовать укреплению международных связей в борьбе с интернет-преступностью в целом.

\section{Литература}

1. Jahankhani H., Al-Nemrat A., Hosseinian-Far A. Cybercrime Classification and Characteristics // Cyber Crime and Cyber Terrorism Investigator's Handbook. Waltham, 2015. 393 p. 
Н. А. Семенова, Т. И. Эрхитуева. Мошенничество в киберпространстве по уголовному законодательству России и Монголии

2. Даваажав Сумъяацэрэн. Актуальные проблемы борьбы с преступностью в сфере информационных технологий в Монголии // Вестник Восточно-Сибирского института МВД России. 2017. № 1. С. 1-5. Текст : непосредственный.

Статья поступила в редакциию 05.09.2021; одобрена после рецензирования 10.10.2021; принята к публикации 08.11.2021.

\title{
FRAUD IN CYBERSPACE UNDER CRIMINAL LAWS OF RUSSIA AND MONGOLIA
}

\author{
Natalya A. Semyonova \\ Lecturer \\ 624559@list.ru
}

Tatyana I. Erkhiteeva

Cand. Sci. (Law), A/Prof.

tanja_77@mail.ru

Dorzhi Banzarov Buryat State University

6 Sukhe-Batora St., Ulan-Ude 670000, Russia

Abstract. Russian-Mongolian relations are based on a long history of bilateral interaction, they are all-encompassing and characterized by traditional good-neighborliness. The fight against cyber-theft holds a special place in Russia and Mongolia.

The criminal laws of both countries provide for criminal liability for fraud in the field of information and telecommunication technology or computer information.

The study of this type of fraud is also relevant, since in 2016 the new Criminal Code of Mongolia was adopted. In this regard, criminal regulation of cyberspace fraud in Mongolia is of special interest. There are some differences in the definition of fraud in criminal laws of Russia and Mongolia, however, the patterns of social engineering used by fraudsters in both countries have much in common.

Keywords: criminal law, crimes, crime prevention, cybercrime, cyberspace, fraud, theft.

For citation

Semyonova N. A., Erkhiteeva T. I. Fraud in Cyberspace under Criminal Laws of Russia and Mongolia. Bulletin of Buryat State University. Law. 2021; 3: 40-45 (In Russ.).

The article was submitted 05.09.2021; approved after reviewing 10.10.2021; accepted for publication 08.11.2021. 